原著

\title{
糖尿病性網膜症の危険因子としての $\operatorname{Lp}(a)$ の意義について
}

紀田康 雄* 柏木厚 典** 日 高 秀 樹**

\section{I.はじめに}

リポプロテイン (a) (以下 Lp(a)) は疫学調査から冠動 脈硬化の危険因子として注目されてきた ${ }^{1-7)}$. 糖尿病でも Lp(a) が高值であるとする報告が多く, 各種血管合併症と の関連が推察される ${ }^{8-10}$. われわれも Lp(a) が NIDDMで は健常者より高く，腎症と独立した関連を有することを報 告してきた ${ }^{10,11}$. 今回は, 多数例の NIDDM を対象とし網膜 症の危険因子，特に高 $\mathrm{Lp}(\mathrm{a})$ 血症との関係を検討した。

\section{II. 対象と方法}

対象は 600 例 (男 345 例, 女 255 例, 年齢 $60 \pm 12$ 歳) の NIDDM である. 眼科専門医により散曈後に眼底検査を行 い, 前増殖性網膜症の疑われる症例には蛍光眼底検查も 行った. 眼底所見から網膜症のない $\mathrm{N}$ 群 (325 例), 単純性 網膜症群 (毛細血管瘤, 点状出血, 硬性白斑を有す, 以下 S 群, 197 例), 増殖性網膜症群 (前増殖性網膜症: 綿花様白 斑, 静脈異常, 網膜内細小血管異常, または増殖性網膜症： 新生血管, 硝子体出血, 牽引性網膜剝離, 以下 $\mathrm{P}$ 群, 78 例) の 3 群に分類した。 Lp (a) 值に影響しうる透析患者や甲状 腺疾患, 肝硬変, ニセリトロールなどの高脂血症治療薬投 与中の患者は除外した。 早朝空腹時に採血, 尿検査を行い, 血糖, 脂質, アポ蛋白, Lp(a) を既報に準じて測定した ${ }^{10)}$. 試験紙法による尿検査で持続性蛋白尿を認める例を腎症 (十) とし，血尿や尿路感染，腎炎の既往のある例は除外し た。また，早朝第一尿で尿アルブミン濃度を測定した。閉 塞性動脈硬化症 (ASO), 虚血性心疾患 (IHD) の判定は既 報に準じた ${ }^{12,13)}$. 末梢神経障害は，アキレス腱反射の低下・ 消失を陽性とし，自律神経障害は心電図で 100 心拍の R-R 間隔変動係数 $(\mathrm{CV}) \leqq 1.5$ ，または Schellong テストで起立

\footnotetext{
$*$ 第二岡本総合病院糖尿病科

** 滋賀医科大学第三内科

原稿受取日：1995 年 8 月 25 日

採用決定日：1995 年 9 月 28 日
}

時収縮期血圧低下 $(\triangle \mathrm{SBP}) \geqq 30 \mathrm{mmHg}$ を陽性とした。 IHD や自律神経障害の有無を判定できなかった少数例は, 統計 処理時に除外している. 高血圧はWHO の基準に基づい た. 以下の結果は， $\mathrm{M} \pm \mathrm{SD}$ で表した。2 群の平均值の比較 は Student t-test, 多群比較には Scheffe の多重比較, 頻度の 差は $\chi^{2}$ 検定, Lp(a) の多群比較は Kruskal-Wallis, 2 群比 較にはWilcoxon 検定, 多変量解析には判別分析を用いた。

\section{III. 成 績}

\section{1) 3 群の臨床的特徵と Lp(a)}

Table 1 に示すように，3群間に性差，BMI，中性脂肪， HDL-コレステロール (HDL-C), アポタンパク-Al (ApoA1),アポタンパク-B (ApoB) に有意差はなかったが, 年齢, 糖尿病歴は有意に $\mathrm{S}$ 群, $\mathrm{P}$ 群で高值であった。空腹 時血糖と HbAlc は, $\mathrm{S}$ 群が $\mathrm{N}$ 群より有意に高值であった。 $\mathrm{Lp}(\mathrm{a})$ は $\mathrm{N}$ 群と比べ $\mathrm{S}$ 群には差はなかったが, P 群は有意 に高值であった。総コレステロール (Tot CHO), 血清クレ アチニン (s-Cr) は $\mathrm{P}$ 群が N 群より有意に高值であった。 $\mathrm{CV}, \Delta \mathrm{SBP}$ ともに S 群, $\mathrm{P}$ 群が $\mathrm{N}$ 群より有意に低く, $\mathrm{P}$ 群 は $\mathrm{S}$ 群よりさらに低值であった。喫煙, 飲酒率は 3 群間に 差がないが, 高血圧は $\mathrm{P}$ 群が, インスリン治療は $\mathrm{S}$ 群, $\mathrm{P}$ 群 が N 群より高頻度であった。

なお，本施設の健常者 39 例 (男性 20，女性 19 例，年齢 $58 \pm 8$ 歳) で測定した $\mathrm{Lp}$ (a) は $13 \pm 9$ で， Lp(a) の基準值 を $31 \mathrm{mg} / \mathrm{dl}(\mathrm{M} \pm 2 \mathrm{SD})$ とすると，32 以上の高 $\mathrm{Lp}(\mathrm{a})$ 血症 は， N 群 58 例， S 群 41 例，P群 26 例で，P群は $\mathrm{N}$ 群，S 群より有意に高 $\mathrm{Lp}(\mathrm{a})$ 血症が多かった (各々 $\mathrm{p}<0.01, \mathrm{p}<$ 0.05).

\section{2） 3 群の糖尿病合併症の頻度と生命予後}

Table 2 に, 3 群の各種合併症の頻度を示した. 網膜症の 程度と他の合併症の頻度の間には密接な関連性がみられ る.P群はすべて N 群より高頻度で, IHD 以外はいずれも $\mathrm{S}$ 群より高頻度であった。 また, 観察期間 4 年間での死亡率 は， $\mathrm{P}$ 群が $\mathrm{N}$ 群， $\mathrm{S}$ 群より有意に高かった。死亡した $\mathrm{P}$ 群 
Table 1 Characteristics of the subjects.

\begin{tabular}{lccc}
\hline \multicolumn{1}{c}{ Group } & $\mathrm{N}$ & $\mathrm{S}$ & $\mathrm{P}$ \\
\hline No (\%) & 325 & 197 & 78 \\
Gender (M/F) & $195 / 130$ & $110 / 87$ & $40 / 38$ \\
Age (y) & $58 \pm 12$ & $62 \pm 11^{* *}$ & $62 \pm 11^{* *}$ \\
Duration (y) & $5 \pm 6$ & $11 \pm 8^{* *}$ & $15 \pm 8^{* *}$ \\
BMI (kg/m $)$ & $23.7 \pm 3.6$ & $22.8 \pm 3.4$ & $23.2 \pm 3.8$ \\
EPG (mg/dl) & $168 \pm 65$ & $187 \pm 66^{*}$ & $178 \pm 65$ \\
HbAlc (\%) & $8.0 \pm 2.3$ & $8.7 \pm 2.2^{* *}$ & $8.5 \pm 2.1$ \\
Lp(a) (mg/dl) & $21 \pm 20$ & $22 \pm 19$ & $27 \pm 20^{* *}$ \\
\# Lp(a) & $15(1 \sim 135)$ & $18(1 \sim 165)$ & $22(1 \sim 100)$ \\
Tot CHO (mg/dl) & $218 \pm 54$ & $212 \pm 48$ & $238 \pm 65^{*} \$$ \\
TG (mg/dl) & $163 \pm 114$ & $149 \pm 85$ & $164 \pm 115$ \\
HDL-C (mg/dl) & $47 \pm 15$ & $49 \pm 16$ & $47 \pm 15$ \\
ApoA1 (mg/dl) & $134 \pm 29$ & $137 \pm 33$ & $131 \pm 27$ \\
ApoB (mg/dl) & $113 \pm 29$ & $108 \pm 28$ & $119 \pm 35$ \\
s-Cr (mg/dl) & $1.0 \pm 0.2$ & $1.1 \pm 0.3$ & $1.6 \pm 1.7^{* *}$ \\
Log (u-Albumin) & $1.2 \pm 0.4$ & $1.6 \pm 0.7^{* *}$ & $2.2 \pm 0.9^{* * \$}$ \\
CV & $2.7 \pm 1.1$ & $2.1 \pm 1.0^{* *}$ & $1.5 \pm 0.7^{* * \$} \$$ \\
ASBP (mmHg) & $-9 \pm 11$ & $-13 \pm 16^{*}$ & $-24 \pm 23^{* * \$}$ \\
Hypertension & $184 / 141$ & $96 / 101$ & $27 / 51^{* * \$} \$$ \\
Smoking (-/+) & $151 / 174$ & $94 / 103$ & $39 / 39$ \\
Alcohol (-/+) & $214 / 111$ & $141 / 56$ & $61 / 17$ \\
Treatment of DM & $144 / 121 / 60$ & $33 / 85 / 79^{* *}$ & $8 / 25 / 45^{* *} \$$ \\
(Diet/SU/Insulin) & & & \\
\hline
\end{tabular}

Abbreviation, Group $\mathbf{N}$ : retinopathy(-), $\mathbf{S}$ : simple retionopathy, $\mathbf{P}$ : proliferative retinopathy, BMI : body mass index, $\mathrm{CV}: \mathrm{R}-\mathrm{R}$ interval variation, $\triangle \mathrm{SBP}$ : change of systolic blood pressure on standing.

\#: Data are expressed as median (range).

${ }^{*} \mathrm{p}<0.05,{ }^{* *} \mathrm{p}<0.01$ vs Group N, $\mathrm{p}<<0.01$ vs Group $\mathrm{S}$

Table 2 Incidence of other complication and life prognosis.

\begin{tabular}{lccc}
\hline \multicolumn{1}{c}{ Group } & $\mathrm{N}$ & $\mathrm{S}$ & $\mathrm{P}$ \\
\hline Nephropathy $(-/+)$ & $316 / 9$ & $167 / 30^{*}$ & $46 / 32^{*} \$$ \\
Peripheral neuropathy $(-/+)$ & $228 / 97$ & $73 / 124^{*}$ & $6 / 72 * \$$ \\
Autonomic neuropathy $(-/+)$ & $260 / 59$ & $120 / 71^{*}$ & $23 / 55^{*} \$$ \\
IHD $(-/+)$ & $205 / 83$ & $90 / 77^{*}$ & $32 / 32^{*}$ \\
ASO $(-/+)$ & $289 / 21$ & $173 / 19$ & $53 / 20 * \$$ \\
Gangrene $(-/+)$ & $324 / 1$ & $195 / 2$ & $68 / 10^{*} \$$ \\
Died $(-/+)$ & $322 / 3$ & $189 / 8^{*}$ & $69 / 9 * \$$ \\
\hline
\end{tabular}

Abbreviation, Group $\mathbf{N}$ : retinopathy $(-), \mathbf{S}$ : simple retinopathy, $\mathbf{P}$ : proliferative retinopathy, IHD : ischemic heart disease, ASO : arteriosclerosis obliterance.

${ }^{*} \mathrm{p}<0.01$ vs Group N, $\$ \mathrm{p}<0.01$ vs Group S

9 例の死因は, 脳梗塞 2 例, 脳出血 1 例, 心筋梗塞 2 例, 腎 不全 2 例, 突然死 1 例, 子宮癌 1 例であった。

\section{3) $\mathbf{L p}(\mathbf{a})$ と腎症，糖尿病治療の影響}

今回の対象では $\mathrm{Lp}(\mathrm{a})$ に男女差はみられなかった。腎症 と Lp(a) はすでに報告してきたように相関し，腎症 $(+)$ 群の Lp(a) は (一) 群より有意に高值であった $(21 \pm 20$ vs $28 \pm 21, \mathrm{p}<0.01)$. また, $\mathrm{Lp}(\mathrm{a})$ と尿アルブミン排泄量と の間にも有意な相関を認めた $(\mathrm{r}=0.29, \mathrm{p}<0.01)$.
しかし, 食事療法, 経口郕, インスリン治療の 3 群の Lp(a) には差はなかった。 Lp(a) は, 腎症の影響をうけるため腎 症の有無で2 群に分けて検討した結果を Fig. 1 に示した。 腎症 (一) 群の Lp(a) は, N 群より P 群が $20 \%$ 高值である が有意差はなく, 腎症 (十) 群でも P 群の $\mathrm{Lp}(\mathrm{a})$ は N 群よ り $50 \%$ 高值であったが有意ではなかった。腎症 $(-)$ の $\mathrm{P}$ 群や腎症 (十)の $\mathrm{N}$ 群のように, 腎症と網膜症が解離する 例は多くないため, 今後さらに症例を増やして検討する必 
Table 3 Discriminant analysis (stepwise method). Diabetic retionopathy versus factors including age, sex, duration of DM, HbAlc, insulin treatment, autonomic neuropathy, nephropathy, hypertension, total cholesterol, and $\mathrm{Lp}(\mathrm{a})$.

\begin{tabular}{lllc}
\hline \multicolumn{2}{c}{$\begin{array}{c}\text { Simple or proliferative retiopathy } \\
\text { Variables }\end{array}$} & \multicolumn{2}{c}{$\begin{array}{c}\text { Proliferative retinopathy } \\
\text { Variables }\end{array}$} \\
\hline Duration & $\mathrm{p}<0.0001$ & Nephropathy & $\mathrm{p}$-value \\
Insulin treatment & $\mathrm{p}<0.0001$ & Autonomic neuropathy & $\mathrm{p}<0.0001$ \\
Nephropathy & $\mathrm{p}<0.0001$ & Duration & $\mathrm{p}=0.0001$ \\
Autonomic neuropathy & $\mathrm{p}=0.0012$ & Tot. CHO & $\mathrm{p}=0.0019$ \\
& & Insulin treatment & $\mathrm{p}=0.0043$ \\
\hline \multicolumn{2}{c}{ Discriminant probability $=0.73$} & Discriminant probability $=0.74$
\end{tabular}

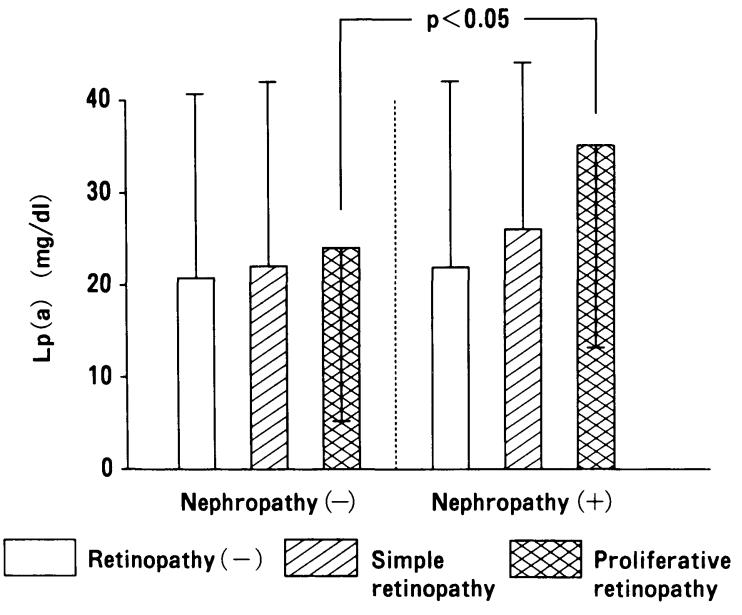

Fig. 1 Relationship between $\mathrm{Lp}(\mathrm{a})$ and severity of retinopathy.

要はあろう.なお, 網膜症の程度が同等の場合は腎症 $(+)$ 群のほうが $($ 一) 群より Lp(a) が高い傾向にあり，腎症 (+) のP群で Lp(a) はもっとも高值であった。

\section{4) 判別分析による網膜症の危険因子}

腎症の有無で分けた場合にも, 網膜症と Lp(a) が有意で はないが相関する傾向が示唆された，そこで，網膜症の有 無を目的変数, 年齢, 性別, 糖尿病歴, HbAlc, インスリ ン治療の有無, 自律神経障害, 腎症, 高血圧, Lp(a), Tot CHOの 10 項目を説明変数として判別分析を行った結果 を Table 3 に示した. Table 3 左に示すように網膜症 (S 群・P 群) と独立した関連を認めたのは, 糖尿病歷, インス リン治療, 腎症, 自律神経障害でいずれも有意であったが, Lp(a) とは関連性を認めなかった。一方, Table 3 右に示す ように増殖性網膜症 (P 群) の危険因子としては, 腎症, 自 律神経障害, 糖尿病歴, Tot CHO, インスリン治療の 5 項 目が独立した関与を示したが，Lp(a) はここでも関連がな かった。

\section{IV. 考察}

近年, 糖尿病性網膜症による視力障害が増加しており, 欧米，本邦ともに中途失明原因の第 1 位を占めるに至って いる14-17).われわれの施設でも両眼失明者は NIDDMの $4 \%$ を占め, 重度の増殖性網膜症が失明の主たる原因であっ た ${ }^{18)}$. 網膜症の危険因子や増悪因子を明らかにし, 制御する ことは網膜症予防の観点からも重要である．網膜症の危険 因子としての高血糖の意義は，Diabetes Control and Complication Trial (DCCT) などの疫学調查結果からも明らか である ${ }^{19-21)}$.さらに，急激な血糖改善，高血圧，血小板凝 集能, 凝固線溶機能, 脳動脈の閉塞, 妊娠, 網膜血行動態 の異常など，さまざまな因子の関与も考えられる ${ }^{22-27)}$.ま た, 高 $\mathrm{Lp}(\mathrm{a})$ 血症との関連性も報告されている.

Lp(a) は，冠動脈硬化の独立した危険因子の一つとさ れ, 病理学的検討でも動脈硬化巣で $L p(a)$ の沈着も証明さ れている1-7,28,29). Lp(a) の Apo(a) がプラスミノゲンと構 造的類似性を有するため, 線溶系に阻害的に働く可能性が ある ${ }^{30-32)}$

糖尿病でも $\mathrm{Lp}(\mathrm{a})$ が高值であるとする報告が多く，われ われも糖尿病患者の $\mathrm{Lp}(\mathrm{a})$ は健常者より高值で, 腎症の独 立した危険因子である可能性を報告してきた ${ }^{10,11,33,34)}$. 同じ 細小血管障害である網膜症との関係にも興味がもたれる. 村上らは，62 例の NIDDM で網膜症の程度と Lp(a) の関 係を調べ, 網膜症 (一) 群と単純性網膜症群では差はなく, 増殖性網膜症群では $\mathrm{Lp}(\mathrm{a})$ が有意に高いと報告してい る ${ }^{35)}$. Onuma らも 132 例の NIDDM で Lp(a) を測定し, 増 殖性網膜症では Lp(a) が有意に高く, 多変量解析でも男性 では Lp(a), TG，インスリン治療，腎症が独立した危険因 子であったが，女性では Lp(a) は関連がなく罹病歴のみ有 意であったとしている ${ }^{36}$. Morisaki らは, 104 例の NIDDM で網膜症と罹病歴，HbAlc, Lp(a)，収縮期血圧が相関し， 多変量解析でも Lp(a), HbAlc が関連を認めたとしている が, 腎症の影響には触れず, 単純性と増殖性網膜症の Lp(a) にも差がなかったとしている37). 牧野らも，120例の 
NIDDM では Lp(a) が健常者より高く, 腎症, 未梢神経障 害, 網膜症と Lp(a) の相互関係をみると網膜症のみ有意で あったとしている ${ }^{38)}$. Maioli らは, 52 例の IDDM で増殖性 網膜症では網膜症 $(-)$ 群と比較し, 脂質, 血圧に差はな かったが Lp(a) が有意に高かったとしている ${ }^{39}$ ．彼らは， Lp(a) の抗プラスミン作用による毛細血管閉塞が増殖性網 膜症と関連があるのではないかと述べているが, 単純性網 膜症に関しては検討していない.

これらの報告は，いずれも網膜症の進行に $\operatorname{Lp}(\mathrm{a})$ が危険 因子として働く可能性を示唆するものである。一方， Winociur らは 90 例の IDDM を対象とし Lp(a) は微量ア ルブミン尿陽性者では高值であるが，網膜症の有無とは関 連がなかったとし, 中田らも, 114 名の NIDDM では腎症 の程度と Lp(a) は相関するが, 心筋梗塞や脳梗塞とは相関 せず，網膜症とも関係なかったとしている ${ }^{40,411}$.このよう に，Lp(a) と網膜症の関連性には賛否両論あるが，この背 景には Lp(a) がノンパラメトリックデータのため症例数 を十分集めないと結論を得にくいことや，Lp(a) と腎症が 密接に相関するため腎症の影響を加味して評価する必要が あることが問題点としてあげられよう。われわれは，糖尿 病に合併した虚血性心疾患や閉塞性動脈硬化症でも非合併 例より Lp(a) が高值であるが, 腎症の有無で補正すると有 意差がなくなることを報告している ${ }^{12,13)}$.

そこで, 以上の点を考慮にいれ 600 例の NIDDM を対象 として網膜症と Lp(a) の関係を調べた。その結果, 網膜症 群は $\mathrm{N}$ 群より有意に高齢で䍜病歷が長く, 他の糖尿病合併 症や高血圧の合併頻度も多かった。断面調査のため血糖に は有意差はなかったが, 網膜症合併例で HbAlc は高い傾 向にあり，䍜病歷やインスリン治療者が多いことから累積 的な高血糖の影響は大であろう。また，P群では Tot CHO や s-Cr 值も高く生命予後も不良であった。 Lp (a) は，3群 比較では $\mathrm{S}$ 群は $\mathrm{N}$ 群と有意差はなかったが, $\mathrm{P}$ 群は有意に $\mathrm{N}$ 群より高值であった。ただし, 多変量解析を行うと網膜 症全体では，糖尿病歷，インスリン治療，腎症，自律神経 障害が, 増殖性網膜症では腎症, 自律神経障害, 糖尿病歷, Tot CHO，インスリン治療，が各々独立した危険因子であ ることが示唆された。しかし，Lp(a) と網膜症との独立し た関係は証明できなかった。 ただし, Fig. 1 に示したように 腎症の有無で 2 群に分けると有意差はないが網膜症が重症 なほど Lp(a) が高い傾向を認めたことから, 高 Lp(a) 血症 が網膜症進展に働いた可能性は否定できない. 今後, 腎症 (一) の P 群や, 腎症 (+) の N 群のカテゴリーにはいる症 例を蓄積するとともに，網膜症発症前の症例を対象として 高 $\mathrm{Lp}$ (a) 血症と網膜症の発生率や進展速度との関連性を 前向き調査にて検討する必要があろう。

なお，本研究を行うにあたり，多数の糖尿病患者の眼底
検査にご尽力いただいた第二岡本総合病院眼科，三浦寛一 部長とご指導, ご校閲を賜った滋賀医科大学第 3 内科, 吉 川隆一教授に謝意を表します。

\section{V. 結 論}

腎症を有する糖尿病患者では，Lp(a) が高值であること が報告されてきたが, 網膜症の危険因子としての Lp (a) の 意義は明らかではない，そこで今回われわれは，600例の NIDDM を対象として Lp(a) を測定し, 網膜症の危険因子 としての意義を調べた。単純性網膜症と増殖性網膜症は 各々 33\% (197 例)，13\% (78 例) の頻度であった。網膜症合 併例は, 高齢で罹病歴が長く, 血糖と尿アルブミン排泄が 高い傾向を認めた。さらに, 網膜症例は高血圧や他の血管 合併症，インスリン治療者の頻度が高かった。増殖性網膜 症を有する例は網膜症非合併例より有意に Lp(a) が高値 であった。しかし腎症患者では Lp(a) が有意に高いため, 腎症の有無で補正すると $\mathrm{Lp}(\mathrm{a})$ と網膜症の有意な相関は なかった。多変量解析では網膜症の危険因子として糖尿病 歴, インスリン治療, 腎症, 自律神経障害が有意な関連を 示したが, Lp(a) とは独立した関連性は証明できなかった。

\section{文献}

1) Armstrong VW, Crener P, Eberle E, Manke A, Schulz F, Wieland $\mathrm{H}$, Kreuzer $\mathrm{H}$, and Seidel $\mathrm{D}$ : The association between serum $\mathrm{Lp}$ (a) concentrations and angiographically assessed coronary atherosclerosis. Atherosclerosis, 62: 249-257, 1986

2) Dahlen GH, Guyton JR, Attar M, Farmer JA, Kautz JA, and Gotto AM: Association of levels of lipoprotein $\mathrm{Lp}(\mathrm{a})$, plasma lipids, and other lipoproteins with coronary artery disease documented by angiography. Circulation, 74: 758-765, 1986

3) Kostner GM, Avogaro P, Cazzolato G, Marth E, Bittolo-Bon G, and Qunici GB : Lipoprotein Lp(a) and the risk for myocardial infaction. Atherosclerosis, 38 : 51-61, 1981

4) Seed M, Hoppichler F, Reaveley D, McCarthy S, Thompson GR Boerwinkle E, and Uttermann G: Relation of serum lipoprotein (a) concentration and apolipoprotein (a) phenotype to coronary heart disease in patients with familial hypercholesterolemia. N Engl J Med, 322 : 1494-1499, 1990

5) Rosengren A, Wilhelmsen M, Eriksson E, Risberg E, and Wedel $\mathrm{H}$ : Lipoprotein (a) and coronary heart disease: a prospective case-control study in a general population sample of middleaged men. $\mathrm{Br}$ Med J, 301 : 1248-1251, 1990

6) Scanu AM : Lipoprotein (a). A genetic risk factor for premature coronary heart disease. JAMA, 267: 33263329, 1992

7) Yamamura $T$, Nomura S, Yang X, Toyota $Y$, Sonobe M, Yamamoto A, Haze K, Hiramori K, Hara H, 
Yamaguchi T, and Pokrovsky SN : Lipoprotein (a) in ischemic heart disease and cerebrovascular disease. $\mathrm{J}$ Atherosclerosis and Thrombosis 2(suppl),: S13-S16, 1995

8) Bruckert E, Davidoff P, Grimaldi A, Truffert J, Giral P, Doumith R, Thervet F, and De Gennes JL: Increased serum levels of lipoprotein (a) in diabetes mellitus and their reduction with glycemic control. JAMA, 263 : 35-36, 1990

9) Ramirez LC, Arauz-Pacheco C, Lackner C, Albright G, Adams BV, and Raskin P: Lipoprotein (a) levels in diabetes mellitus: relationship to metabolic control. Ann Intern Med, 117 : 42-47, 1992

10) 紀田康雄, 柏木厚典, 江端一彦, 杉本俊郎, 羽田勝計, 吉川隆一，繁田幸男：NIDDM における糖尿病性腎症 の危険因子，特に高 $\mathrm{Lp}(\mathrm{a})$ 血症の意義。糖尿病， 36 ： 763-770, 1993

11) 紀田康雄, 柏木厚典, 吉川隆一, 繁田幸男 : 糖尿病患者 の細小血管障害と Lp(a), 特に腎症の危険因子として の可能性について. 糖尿病性合併症研究会編, 糖尿病性 合併症，7：124-130, 1994

12）紀田康雄, 柏木厚典, 繁田幸男, 吉川隆一：糖尿病の閉 塞性動脈硬化症における $\mathrm{Lp}(\mathrm{a})$ の意義。糖尿病, 39： 25-30, 1996

13) 紀田康雄, 日高秀樹, 柏木厚典, 繁田幸男: 糖尿病患者 における虚血性心疾患の危険因子，特に Lp(a) の意義 について. 動脈硬化，23：249-254，1995

14）中江公裕, 小暮文雄, 長屋幸郎, 三島済一：わが国にお ける視覚障害の現況。厚生の指標，38：13-22, 1991

15) 岩尾總一郎: 厚生省の糖尿病対策について。糖尿病, 38(suppl) : 95, 1995

16) Ferris FL 3rd: Diabetic retinopathy. Diabetes Care, 16: 322-325, 1993

17) Moss SE, Klein R, and Klein BE : Ten-year incidence of visual loss in a diabetic population. Ophthalmology, 101 : 1061-1070, 1994

18) 紀田康雄, 柏木厚典, 居出理恵, 川端 徹, 阪本勝彦, 吉川隆一：インスリン非依存型糖尿病における中途失 明者の頻度と生命予後. 糖尿病 (投稿中)

19) The Kroc Collaborative Study Group: Diabetic retinopathy after two years of intensified insulin treatment. JAMA, 260: 37-41, 1988

20) Klein R, Klein BEK, and Moss SE : Glycosilated hemoglobin predicts the incidence and progression of diabetic retinopathy JAMA, 260 : 2864-2871, 1988

21) The Diabetes Control and Complication Trial: The effect of internsive treatment of diabetes on the development and progression of long-term complications in insulin-dependent diabetes. N Engl J Med, 329: 977986, 1993

22) 福田全克 : 眼合併症, 糖尿病と合併症, 第 1 版, pp 100114, 繁田幸男, 吉川隆一編集, 医歯薬出版社, 東京, 1994

23) Kohner EM, Patel V, and Rassam SMB : Role of blood flow and impaired autoregulation in the pathogenesis of diabetic retinopathy. Diabetes, 44 : 603-607, 1995

24) Knowler WC, Bennett PH, and Ballintine EJ : Increased incidence of retinopathy in diabetics with elevated blood pressure. N Engl J Med, 302 : 645-650, 1980

25) Moskalets E, Galstyan G, Starostina E, Antosiferov M, and Chantelau E: Association of blindness to intensification of glycemic control in insulin-dependent diabetes mellitus. J Diabetes Complications, 8 : 45-50, 1994

26）水本博幸，田宮宗久，松田 彰，松谷久美子，伊古田 明美, 紅粉睦男, 真尾泰生 : 入院による急速な血糖改善 が網膜症に及ぼす影響 (第一報). 糖尿病, 37：471-477, 1994

27) 竹田宗泰 : 糖尿病性網膜症，腎症との関連. Diabetes Frontier, 1: 229-233, 1990

28) Pepin JM, O'Neil JA, and Hoff HF : Quantification of apo(a) and apoB in human atherosclerotic lesion. J Lipid Res, 32 : 317-327, 1991

29) Rath $M$ : Detection and quantification of lipoprotein (a) in the arterial wall of 107 coronary bypass patients. Arteriosclerosis, 9: 579-592, 1989

30) Mbewu AD, and Durrington PN : Lipoprotein (a) : structure, properties and possible involvement in thrombogenesis and atherogenesis. Atherosclerosis, $85: 1-14$, 1990

31) Simon DI, Fless GM, Scanu AM, and Loscalzo J : Tissue type plasminogen activator binds to and inhibited by surface-bound lipoprotein (a) and low density lipoprotein. Biochemistry, 30:6671-6677, 1991

32) Hajjar KA, Gavish D, Breslow JL, and Nachman RL: Lipoprotein (a) modulation of endothelial cell surface fibrinolysis and its potential role in atherosclerosis. Nature, 339 : 303-305, 1989

33) Kapelrud H, Bangstad HJ, Dahl-Jorgensen K, Berg K, and Hanssen KF : Serum Lp(a) lipoprotein concentration in insulin dependent diabetic patients with microalbuminuria. Br Med J, 303: 675-678, 1991

34) Takegoshi T, Haba T, Hirai J, Kitoh C, Sega $T$, Yamazaki $\mathrm{Y}$, and Mabuchi $\mathrm{H}$ : Alterations of lipoprotein (a) in patients with diabetic nephropathy. Atherosclerosis, 83 : 99-100, 1990

35) 村上純子, 熊坂一成, 河野均也, 村上哲雄, 林 洋一, 荒川泰行：糖尿病患者の血清 $\mathrm{Lp}(\mathrm{a})$. 臨床病理, 42 ： 1273-1278, 1994

36) Onuma T, Kikuchi T, Shimura M, Tsutsui M, Matsui J, Boku A, and Takebe K : Lipoprotein (a) as an independent risk factor for diabetic retinopathy in male patients in non-insulin-dependent diabetes mellitus. Tohoku $\mathbf{J}$ Exp Med, 173 : 209-216, 1994

37) Morisaki N, Yokote K, Tashiro J, Inadera H, Kobayashi J, Kanzaki T, Saito Y, and Yoshida S : Lipoprotein (a) is a risk factor for diabetic retinopathy in the elderly. $\mathbf{J}$ Am Geriatr Soc, 42 : 965-967, 1994

38) 牧野和彦, 前田悟司, 安部 彰, 川出真坂, 野間昭夫, 安田圭吾，三浦 清: インスリン非依存型糖尿病にお ける Lp(a) リポ蛋白について. 動脈硬化, 18：833-837, 1990

39) Maiolo M, Tonolo G, Pacifico A, Ciccarese M, Brizzi P, Kohner EM, and Porta M: Raised serum apolipoprotein (a) in active diabetic retinopathy. Diabetologia, 36: 88-90, 1993

40) Winocour PH, Bhantnagar D, Ishola M, Arrol S, and Durrington PN : Lipoprotein (a) and microvascular disease in type 1 (insulin-dependent) diabetes. Diabetic 
Med, 8: 922-927, 1991

41) 中田宏志, 関口雅友, 森川秋月：NIDDM 患者における
血中 Lipoprotein (a) 濃度の上昇と血糖コントロール の関連性. 糖尿病, 34: 1047-1053, 1991

\title{
Summary
}

\section{Significance of Serum $\operatorname{Lp(a)}$ Concentration as a Risk Factor for Diabetic Retinopathy}

\author{
Yasuo KIDA*, Atsunori KaSHIwaGi**, and Hideki HIDAKA** \\ *Department of Diabetes, Dainiokamoto General Hospital, \\ **Third Department of Medicine, Shiga University of Medical Science, Siga Japan
}

\begin{abstract}
Although an elevated level of $L p(a)$ has been reported in diabetic patients with nephropathy, the significance of $\mathrm{Lp}(\mathrm{a})$ as a risk factor for diabetic retinopathy (DR) is still not clear. Thus, we determined the serum Lp(a) levels in 600 patients with NIDDM and evaluated clinical implication of $\mathrm{Lp}(\mathrm{a})$ as a risk factor for DR. Simple DR or proliferative DR was diagnosed in $33 \%(n=197)$ and $13 \%(n=78)$, respectively. The subjects with DR tended to be older, with a longer duration of diabetes, higher plasma glucose levels and urinary albumin excretion. Furthermore, the subjects with DR were frequently associated with hypertension, other vascular complica-
\end{abstract}

tions, and insulin treatment. The serum $\mathrm{Lp}$ (a) concentrations in proliferative DR were significantly higher than that in subjects without DR. The serum Lp(a) level in NIDDM was elevated in nephropathic patients. When adjusted for nephropathy, $\mathrm{Lp}(\mathrm{a})$ was not correlated significantly with DR. Discriminant analysis demonstrated that the duration of diabetes, insulin treatment, nephropathy, and autonomic neuropathy, but not $L p(a)$ concentration, could be an independent risk factor for retinopathy in patients with NIDDM.

Key words : Retinopathy, Diabetes mellitus, Risk factor, Hyperlipidemia, Lipoprotein (a) 